\title{
Dunia Kontemporer: Trauma Atau Nostalgia
}

\author{
Wibi Hambalie \\ Mahasiswa Jurusan Hubungan Internasional, Fakultas IImu Sosial dan IImu Politik, \\ Universitas Katolik Parahyangan
}

\begin{abstract}
Abstrak
Keadaan dunia dan konstruksi sosial didalamnya tidak lahir secara instan melainkan melalui sebuah perjalanan panjang dan proses pemasukan nilai-nilai sosial kedalam konstruksi sosial. Berbicara tentang sebuah perjalanan dan proses pemasukan nilai tentu tidak akan lepas dari dua hal utama, yaitu waktu dan manusia. Waktu akan menjadi bermakna ketika ada nilai dari sebuah fenomena yang mengisinya dan nilai dalam waktu hanya bisa diberikan oleh manusia yang hidup pada masa itu saja. Emosi yang dimiliki manusia akan menentukan nilai dan makna apa yang diberikan pada waktu yang akan mengubah kedua hal tersebut menjadi sebuah konstruksi sosial. Perasaan senang, sedih, bangga, dsb akan memaknai peristiwa yang bersama dengan waktu akan melahirkan konstruksi sosial yang utuh. Kejadian seperti holocaust, Perang Dunia, dan Perang Dingin secara tidak langusng berkontribusi dalam pembentukan konstruksi sosial dalam dunia yang sekarang kita tinggali. Ketidakpercayaan hanyalah sebagian kecil warisan yang kita dapat dari peristiwa tersebut, meskipun setelah sekian lama usai apakah kita hidup dalam dunia yang trauma atau dunia yang sudah berhasil pulih adalah sebuah pertanyaan yang menarik untuk membantu memahami fenomena internasional yang terjadi saat ini.

Kata kunci: konstruksi sosial, waktu, manusia, makna, emosi, trauma, nostalgia, kesadaran, fenomena internasional
\end{abstract}

\section{PENDAHULUAN}

Konstruksi sosial terlebih secara luas yaitu konstruksi dunia tidak dapat terlepaskan dari kehadiran manusia sebagai komponen utama dalam rantai penyusun konstruksi itu sendiri. Berbagai kejadian telah memicu manusia untuk belajar dalam memaknai dan seolah memaksa manusia untuk berubah sesuai dengan besar kecilnya dampak atas kejadian tersebut. Makna yang tercipta berupa perang atau perdamaian, yang akan menjadi sebuah warisan bagi generasi selanjutnya. Salah satu keunikan dari manusia adalah seringkali mereka berhasil menciptakan sebuah kondisi ilusi dimana makna dan penafsiran personal dapat berbeda satu dengan lainnya. Apa yang menjadi rentan adalah ketika suatu peristiwa dimaknai secara tidak tepat oleh karena adanya dorongan psikologis sang penafsir yang menjauhkan dirinya dari kebenaran

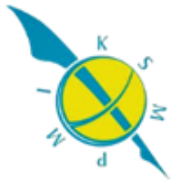


yang sesungguhnya dan kesalahan penafsiran tersebut menjadi sebuah warisan bagi generasi selanjutnya. Konstruksi dunia yang merupakan perpaduan persepsi dan konsepsi manusia akan dunia itu sendiri secara ideal tidak dapat mentolerir adanya kesalahan dalam konstruksi, karena akan merusak sesuatu yang akan menghancurkan konstruksi yang tercipta.

Sesuatu yang demikian rapuh, tetapi menjadi sebuah fondasi dasar bagi manusia dalam perjalanan waktu yang demikian panjang dan tidak dapat diprediksi setiap dinamika yang akan mendampinginya. Bagaimana dunia saat ini, sebagai dunia yang telah mengalami berbagai peristiwa dari perang yang bertujuan untuk mendapat kekuatan hingga mengalami perang yang bertujuan untuk mengakhiri perang itu sendiri pernah terjadi dan setiap individu yang menyaksikan dan mewariskan pengalaman dan tafsiran mereka kepada generasi selanjutnya. Pengalamanpengalaman yang diwariskan secara tidak langsung turut menciptakan konstruksi dunia saat ini. Apa yang kita alami pada masa hidup kita merupakan warisan atas apa yang dialami oleh generasi sebelumnya. Bagaimana kita sebagai individu dalam sebuah negara mendapat pelajaran mengenai masa perjuangan dan konsepsi atas perjuangan melawan penjajahan atau semacamnya menciptakan sesuatu di dalam alam bawah sadar kita sebagai individu yang menerima informasi dengan cara yang demikian rupa memandang bekas penjajah sebagai sebuah musuh meskipun sesungguhnya itu adalah sebuah sejarah semata.

Ilusi, inilah yang sangat dikhawatirkan berdampak buruk pada konstruksi sosial. Berbagai pandangan negatif yang tidak terbatas pada cara pandang antar pihak yang pernah berseteru di masa lalu, seharusnya pada masa kini yang perlu dipetik adalah bagaimana mencegah kejadian serupa terulang bukan menjadi sebuah kebencian. Dunia yang ideal sebagaimana diimpikan oleh kaum utopis dapat menjadi sebuah realitasnamun melihat berbagai hal yang menimbulkan ketidakpercayaan antar manusia.

Manusia dengan tingkat intelektual tinggi seharusnya mampu memisahkan informasi dan nilai secara objektif untuk menciptakan konstruksi sosial yang ideal,

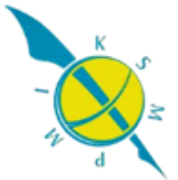


namun pada kenyataannya manusia masih tidak dapat melakukan hal tersebut. Fenomena-fenomena internasional yang terjadi seperti peristiwa 9/11 memicu reaksi Amerika Serikat yang menjadi sangat defensif atau jika lebih jauh, scramble for Africa dapat memberikan makna ketidakpercayaan dan rasa trauma atas dampak yang ditimbulkan.

Di sisi lain, sejumlah upaya rekonsiliasi antara pihak yang pernah bertarung dalam perang besar seperti Jerman mengakui Adolf Hitler adalah bagian dari mereka dan Jerman merasa malu atas apa yang diperbuatnya, serta meminta maaf atas kejadian tersebut memberikan nostalgia bagi individu yang tercakup didalamnya. Warisan yang didapat oleh generasi ini dalam bentuk ketakutan atas keberulangan sejarah dilihat dari sejumlah kejadian seperti pelarangan penggunaan nama "Hitler" dan pemunculan mispersepsi melalui pencantuman sejumlah negara penjajah sebagai musuh disejumlah buku pelajaran anak-anak. memunculkan sebuah pertanyaan berkaitan dengan kondisi konstruksi sosial saat ini yaitu, “Apakah kita hidup dalam dunia yang berada dalam kondisi trauma atau sedang bernostalgia semata?"

Pernyataan tesis penulis terhadap pertanyaan penelitian yang diajukan adalah bahwa dunia beserta konstruksinya masih dalam tahap pembangunan. Dunia akan membutuhkan waktu untuk membuat konstruksi atas dirinya melalui pengumpulan pandangan dan makna atas setiap peristiwa yang berkontribusi menyusun konstruksi sosial. Perang dan perdamaian, kepedihan dan kebahagiaan, trauma dan nostalgia, merupakan aspek pembentuk yang kuat bagi konstruksi sosial. Tidak dapat dipungkiri bahwa manusia memaknai setiap kejadian secara subjektif dan butuh sebuah kedewasaan dan keberanian untuk mengubah warisan yang diberikan oleh generasi sebelumnya. Konstruksi akan sangat layaknya? nilai yang membentuknya, akan menjadi sangat fleksibel yang dapat berubah-ubah seiring berjalannya waktu.

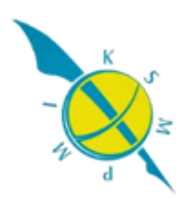




\section{KERANGKA TEORI}

Guna membantu penulis dalam menjawab pertanyaan penelitian maka penulis akan menggunakan teori consciousness oleh Brian O'Shaughnessy. Dalam teorinya akan alam sadar manusia, O’Shaughnessy menjelaskan bahwa setiap manusia memiliki kemampuan alamiah untuk melakukan pengolahan terhadap apa yang mereka rasakan dan akan bertindak terhadap suatu kejadian berdasarkan apa yang mereka inginkan. Kemampuan untuk melakukan pengolahan dan respon tersebut disebabkan oleh hadirnya kesadaran dalam alam pikir manusia. ${ }^{1}$ Dalam teorinya O'Shaughnessy menjelaskan komponen-komponen penyusun kesadaran manusia dan cara kerjanya secara spesifik. Penulis merasa perlu untuk memaparkan kembali tentang komponen-komponen tersebut untuk menjadi dasar pada bagian analisa.

Komponen dalam teori kesadaran O'Shaughnessy yang pertama adalah pengalaman. ${ }^{2}$ Berperan sebagai titik masuk ke dalam alam sadar manusia, pengalaman memegang peran penting dalam membangun sebuah kesadaran. Fenomena akan melahirkan pengalaman dan pengalaman akan melahirkan ingatan yang kelak menjadi sebuah kesadaran. Kesadaran adalah saat dimana kita merekam kejadian disekitar kita dan pengalaman menjadi sebuah hasilnya. Layaknya sebuah sistem, kesadaran dan pengalaman bekerja untuk saling melengkapi, dimana kesadaran merupakan kondisi awal yang sangat diperlukan untuk menghasilkan sebuah pengalaman dan pengalaman adalah hasil yang paling mendekati realitas guna memberikan respon secara nyata. Pengalaman akan sangat bergantung kepada kondisi alam sadar manusia] yang akan melakukan proses untuk memicu munculnya respon tanpa melakukan trial and error terhadap alam sadar kita. Imajinasi yang seringkali muncul dalam alam sadar kita dapat masuk dan dianggap sebagai sebuah

\footnotetext{
${ }^{1}$ Brian O'Shaughnessy. Consciousness and the World. Oxford University. 2002. HIm 4

${ }^{2}$ Ibid, 37
} 
realita yang pernah terjadi dan diproses oleh pengalaman. ${ }^{3}$ Apa yang sebenarnya tidak nyata jika dalam alam sadar kita menyatakan imajinasi tersebut sebagai sebuah realita maka respon yang muncul melalui proses oleh pengalaman pun akan menjadi sesuatu yang semu.

Komponen yang kedua adalah mentalitas. ${ }^{4}$ Setiap individu akan memiliki kondisi mentalitas yang berbeda. Kesadaran manusia setelah disusun oleh pengalaman dilengkapi dengan mentalitas. Sebagaimana disebutkan pada paragraf sebelumnya, pengalaman tidak dapat melakukan proses trial and error atas kejadian namun mentalitas dapat meminimalisir kesalahan pada tahap pengalaman. Mentalitas memiliki peran penting dalam menjaga rasionalitas alam sadar manusia dengan memasukan nilai yang tertanam dalam diri seseorang. Seringkali mentalitas juga berkaitan erat dengan kondisi psikologis seseorang. Setidaknya kedua komponen inilah yang menghasilkan respon atas sebuah kejadian baik yang dialami secara langsung atau berasal dari sebuah imaginasi semata yang dianggap sebagai sebuah kebenaran.Kesadaran manusia melalui pengalaman tidak hanya terbatas pada sebuah peristiwa nyata yang pernah dialami, namun juga melalui pewarisan nilai. Pewarisan nilai seolah membuat ingatan mengatakan bahwa itu merupakan sesuatu yang dialami secara nyata dan berdampak pada hasil dari proses dalam pengalaman yang akan terus menerus melakukan generalisir terhadap sesuatu yang diwariskan.

Hubungan antar individu dalam tulisan kali ini akan menggunakan konsep tentang hegemoni yang dikonsepsikan oleh Antonia Gramsci pada tahun 1916-1935 tentang hegemoni ide. ${ }^{5}$ Menurut Gramsci, hegemoni yang paling mendasar adalah tentang ide dimana masyarakat mempercayai suatu ide dan atas dasar kesadaran bersama mereka akan mengikuti ide tersebut. Aspek-aspek sosial dalam masyarakat yang dipadukan oleh kondisi mentalitas yang nyaris sama, membuat ide akan cepat

\footnotetext{
${ }^{3}$ Ibid, 42

${ }^{4}$ Ibid, 45

${ }^{5}$ Thomas R. Bates. Gramsci and e Theory of Hegemony. University of Pennsylvania Press. 1975. HIm 351
} 
menyebar dan menjadi sebuah singularitas ide di masyarakat. Hegemoni ide dan kesadaran manusia yang berkaitan dalam arti kesadaran satu individu akan menjadi kesadaran pribadi saja, tetapi jika kesadaran tersebut muncul melalui sebuah peristiwa yang melahirkan kesadaran individu yang serupa dan sepikiran maka hegemoni ide akan lahir dari kesadaran bersama.

\section{Trauma Atau Nostalgia}

Manusia dan waktu adalah sesuatu yang berkaitan erat satu sama lain. ${ }^{6}$ Manusia tanpa waktu adalah sebuah entitas tanpa kejelasan dan waktu tanpa manusia akan menjadi sebuah variabel kosong. Waktu bersama dengan manusia akan melahirkan sebuah cerita dan dari cerita akan melahirkan sebuah pengalaman baik secara individu ataupun kolektif. Fenomena-fenomena yang terjadi selama perjalanan panjang umat manusia telah membentuk manusia menjadi sebuah entitas superior dengan segala perkembangan teknologi yang terus dilakukannya dan waktu menjadi sebuah hal yang esensial dan mahal belakangan ini. Manusia bekerja dan berpikir keras untuk melakukan efisiensi dan berlomba dengan waktu,namun yang seringkali terlupakan adalah sebagian besar dari umat manusia hidup dalam waktu yang terhenti. Kejadian-kejadian internasional yang terjadi belakangan ini seperti kasus-kasus rasisme, islamophobia, atau menarik jauh ke masa lalu, holocaust dan pemerkosaan Nanking seolah menjadi sebuah lubang hitam dalam perjalanan umat manusia. Waktu bagi sebagian atau seluruh manusia dengan munculnya ketakutan dan kekhawatiran sebenarnya masih berhenti pada posisi pasca kejadian-kejadian tersebut, mengapa demikian? Pola pikir yang masih tertanam dalam alam sadar manusia, pengalaman semu yang sebenarnya tidak dialami oleh semua orang, dan kesadaran bersama yang tercipta untuk berada dalam pola pikir yang sedemikian rupa, dengan kondisi dan generasi baru yang telah muncul terpaksa mengikuti pola-pola yang dimiliki oleh generasi sebelumnya ?. Generasi baru yang lahir pasca kejadian-kejadian

\footnotetext{
${ }^{6}$ Paul Ricoeur. Time and Matter.
}

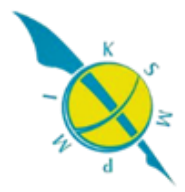


menyakitkan tersebut seharusnya mampu membuat pola pikir baru dan terus mengembangkan peradaban manusia, namun mereka dihentikan oleh pola pikir dan ide-ide yang mendominasi

Mengapa manusia mengingat dan merefleksikannya secara terus menerus meskipun kejadian itu sudah berlalu dan tidak semua orang terdampak secara langsung? Manusia mengingat kejadian disebabkan adanya alam sadar, namun di dalamnya ingatan bekerja seperti dalam penjelasan pada bagian kerangka teori dimana imajinasi juga dapat hadir didalamnya. Ingatan manusia terbagi menjadi dua, secara imajinatif dan secara nyata. Manusia akan ingat secara nyata apa yang ia pelajari, tetapi dapatkah ia mengingat kapan ia mulai mengingat apa yang ia pelajari tersebut ${ }^{7}$ Inilah yang menjadikan ingatan manusia begitu kompleks dan kadang gagal untuk membedakan mana ingatan yang nyata dan mana yang merupakan ingatan imajinatif. Lebih lanjut lagi Socrates dalam sebuah dialog berpendapat, "Ingatan (Mnemoysne) adalah sebuah bakat atau pemberian dari Sang Pencipta. ${ }^{8}$ Seringkali kita memberikan kesan atau makna terhadap semua yang kita harapkan untuk kita ingat berdasarkan apa yang kita lihat dan apa yang kita rasakan yang bersumber dari pikiran kita sendiri.". Masih berlanjut dengan Socrates, "apa yang kita maknai akan selalu meninggalkan kesan dan akan selalu kita ingat serta makna yang sudah kita berikan tidak akan hilang begitu saja tetapi akan menjadi sebuah keabadian dalam pikiran dan kesadaran kita, tetapi apa yang kita tidak maknai dapat hilang.". Merujuk pada pendapat Socrates maka dapat disimpulkan bahwa makna akan berperang penting dalam proses ingatan yang akan berujung pada pengalaman yang akan diwariskan pada diri sendiri ataupun orang lain.

Fenomena-fenomena yang menyakitkan nampaknya akan lebih membekas pada ingatan manusia karena jumlah fenomena tersebut jauh lebih banyak daripada hal-hal yang positif dalam perjalanan umat manusia. Kesadaran manusia akan terbentuk seiring dengan apa yang berjalan beringingan dengan proses pembentukan

\footnotetext{
${ }^{7}$ Brian O'Shaughnessy. Consciousness and the World. Oxford University. 2002. HIm 47

${ }^{8}$ Paul Ricoeur. Memory, History, and Forgetting. Chicago University. 2004. HIm 35
}

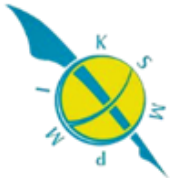


tersebut. Kesadaran yang sudah terlatih untuk melahirkan stigma negatif terhadap suatu pihak atau golongan tertentu akan terus ada jika manusia tidak memaafkan kesalahan atas apa yang terjadi di masa lalu. Apa yang terjadi pada Perang Dunia I dan II, Holocaust, dan Serangan 9/11 akan memamksa manusia yang hidup pada masa-masa tersebut untuk memberikan "penghakiman" dan pengecapan terhadap satu atas lainnya. Beruntunnya kejadian-kejadian yang menyakitkan seolah memancing manusia untuk terus memberikan makna yang negatif dalam ingatan dan kesadaran mereka serta lahirnya pengalaman-pengalaman buruk yang seringkali diwariskan kepada generasi selanjutnya. Menurut Ricoeur, yang akan muncul dari ingatan dan pengalaman buruk yang terjadi secara masif dan bertubi-tubi adalah gejala "overly remembers" terhadap sejarah dan dampaknya adalah waktu yang akan semakin lama terhenti bagi umat manusia. ${ }^{9}$

Bagaimana sesuatu yang bersifat ekslusif seperti pengalaman mampu diwariskan? Pertanyaan ini akan membantu menjelaskan dasar dari bagaimana hegemoni ide sebagaimana Gramsci tuliskan., satu individu sudah menetapkan individu lain sebagai pihak yang harus dimusnahkan atau harus dihindari meskipun sesusungguhnya ia tidak pernah terlihat secara langsung pada permasalahan pertama yang muncul diantara mereka.

Apa yang dirasakan oleh kaum Yahudi pada saat Holocaust terjadi bahkan setelah kejadian tersebut berlalu cukup lama masih membekas bagi kaum yang selamat dan kepada penerus kaum tersebut. Pasca terror 9/11 kemunculan gerakan anti-muslim di Amerika Serikat dapat dipandang sebagai bentuk atas dendam dan kebencian atas apa yang menimpa negara tersebut. Rasa takut dan dendam dapat muncul sebagai pemersatu golongan. Persatuan yang diciptakan oleh kedua emosi tersebut dapat menjadi sebuah bom dimana pada waktu yang acak dapat meledak begitu saja.

\footnotetext{
${ }^{9}$ Ibid, ii
}

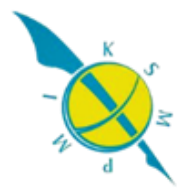


Keinginan yang kuat manusia untuk kembali mencegah kejadian serupa dengan logika jika semua individu yang serupa dengan pelaku dapat dihilangkan maka keamanan akan tercapai menjadi salah satu sisi yang paling menakutkan dari psikologi manusia. Jika ide tersebut yang muncul dalam kondisi ketakutan maka apa yang dikatakan oleh Gramsci dapat menjadi sebuah kenyataan. Layaknya apa yang terjadi di Jerman, yaitu terpilihnya Hitler dengan ide-ide gilanya untuk mengembalikan kejayaan Jerman setelah kalah di Perang Dunia I. Kondisi yang terbentuk melalui penderitaan rakyat Jerman sehingga rasa putus asa tersebut mendorong mereka untuk memilih pilihan yang paling irasional, yaitu memilih Hitler sebagai pemimpin. Ide yang ditawarkan Hitler saat itu begitu mendominasi pikiran warga Jerman kala itu. Apakah kondisi kita saat ini telah berubah atau serupa dengan apa yang terjadi dengan Jerman pada 1939? Ide-ide anti kaum tertentu, antiterhadap agama masih ada diantara kita. Kejadian pembantaian etnis di Jakarta pada akhir periode 1990 dan munculnya sejumlah ormas anarkis yang berusaha melakukan diskriminasi dan tindak kekearasan terhadap etnis tertentu masih turut ada berasama kita hingga detik ini. Apakah kita ada didalam sebuah trauma?

Trauma adalah kondisi psikologis yang terluka akibat suatu kejadian yang tak terduga dan berdampak besar, seringkali diikuti dengan kehilangan orang-orang atau hal yang paling dilindungi. Trauma dapat menjadi sebuah aset pribadi atau dapat melahirkan sebuah trauma yang kolektif. Kejadian yang begitu berdampak kepada suatu komunitas sosial dapat memicu sebuah trauma mendalam pada komunitas tersebut dan lambat laun akan menjadi sebuah hegemoni ide akan suatu hal yang sangat ditakutkan akan terulang kembali. Dalam dunia nyata kita hari ini, sejumlah pertanda akan masih adanya trauma dalam konstruksi sosial kita, sebagai contoh protes yang disuarakan oleh Tiongkok ketika mengetahui PM Jepang, Shinzo Abe berkunjung ke Kuil Yasukuni yang merupakan tempat bersemayamnya tentara

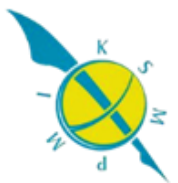


Jepang. ${ }^{10}$ Apa yang diproteskan oleh Tiongkok adalah bahwa kunjungan Shinzo Abe seolah tidak menghormati sejarah yang dirasakan oleh Tiongkok. Kuil Yasukuni diketahui sebagai tempat para pejuang Jepang yang melakukan kekejaman terhadap warga Tiongkok pada zaman penjajahan Jepang di masa lalu. Meskipun terkesan sebagai penghormatan oleh Shinzo Abe yang merupakan warga Jepang, tetapi apa yang ia lakukan seolah membangkitkan luka lama warga Tiongkok yang menjadi korban dari kekejaman Jepang di masa lalu. Kejadian yang sudah berlalu setidaknya sudah melewati tiga dekade lamanya secara nyata masih memicu reaksi yang demikian lantang, hal ini sangat mungkin terjadi karena kesadaran yang diwariskan oleh generasi. Dari sisi warga Tiongkok kita dapat melihat adanya sebuah kesadaran dalam individu-individu yang terakumulasi dan berubah menjadi sebuah pengalaman bersama yang pahit melahirkan sebuah ide akan ketakutan.

Waktu dalam hal ini memainkan peran yang sangat penting, dalam tiga dekade yang berlalu setidaknya ketakutan yang mencekik warga Tiongkok berangsur menurun intensitasnya namun bukan berarti menghapus ingatan akan kejadian tersebut. Manifestasi dari sebuah emosi, menurut O’Shaughnessy dapat masuk ke alam bawah sadar dan menjadi sebuah stigma. Pada kasus Tiongkok perasaan takut setelah melalui perjalanan waktu dan lintas generasi telah berubah menjadi sebuah trauma. Trauma yang telah berada di alam bawah sadar manusia dapat terpicu kapan saja dan dalam tahapan yang berbeda pula untuk setiap individu. Waktu juga telah memberikan kesempatan bagi Tiongkok dan Jepang untuk menjalin kembali hubungan mereka baik melalui kerjasama ekonomi dan pada beberapa kesempatan pula Shinzo Abe menyampaikan pidato untuk meminta maaf atas sejarah yang pernah berulang. Kerjasama dan pidato untuk memperbaiki hubungan kedua negara di masa lalu terbukti hanya menjadi lapisan tipis pencegahan bangkitnya trauma dan pecah ketika Shinzo Abe terbukti melakukan kunjungan ke Kuil Yasukuni. Peristiwa

\footnotetext{
${ }^{10}$ The Guardian. China Protests At Japanese PM's Latest WW2 Shrine Tribute. 17 October 2014. https://www.theguardian.com/world/2014/oct/17/china-protests-japan-shinzo-abeyasukuni-shrine diakses pada 15 November 2016
} 
selanjutnya yang menggambarkan kondisi traumatik dalam masyarakat dunia adalah kondisi pasca serangan 9/11 gedung WTC Amerika Serikat. Pasca serangan mulai bermunculan sejumlah serangan terhadap warga muslim di Amerika Serikat dan jumlahnya meningkat setiap tahunnya. ${ }^{11}$ Ketakutan kembali muncul dalam kesadaran warga Amerika Serikat, tindakan penyerangan dapat dikatakan sebagai bentuk hegemoni ide bahwa muslim adalah teroris dan perlu untuk dibersihkan oleh tangan sejumlah orang-orang yang "termakan" oleh ide tersebut.

Berbeda dengan kasus Jepang-Tiongkok, pada kasus ini waktu belumlah melewati dua dekade dan kondisi yang tercipta seringkali memicu ketakutan yang mendorong tindak kekerasan kepada kaum muslim. Hingga tahun 2016 tindakan kekerasan terhadap umat muslim di Amerika Serikat masih terjadi dan hal ini menunjukan bahwa dalam proses kesadaran manusia, informasi dan kondisi melahirkan sebuah kondisi yang sebenarnya ilusi dalam arti serangan teror sebenarnya sudah berlalu namun pengalaman menghasilkan sebuah outcome yang buruk dan diterima oleh kesadaran sebagai sebuah pembelajaran. Berangkat dari pembelajaran tersebut secara naluri dan sifat "buas" yang dimiliki oleh setiap individu, tindakan kekerasan muncul sebagai bentuk pertahanan diri dan pencegahan untuk teror yang sebelumnya, sebuah ide kolektif seolah menjelma menjadi sebuah dogma. Kondisi traumatik ini juga diperparah oleh sejumlah kejadian teror seperti teror bom saat lomba lari di Amerika Serikat dan sejumlah pidato kebencian terhadap muslim yang beredar di media sosial.

Sejenak kita tinggalkan tentang trauma dan melihat apakah kita hanya berada dalam sebuah nostalgia semata? Nostalgia dapat diartikan sebagai sebuah kondisi dimana individu atau kelompok mengingat sebuah kejadian yang pernah terjadi dan belajar dari kejadian tersebut. Nostalgia dalam alam pikiran manusia, layaknya trauma juga mendapat tempat di bagian alam bawah sadar manusia. Apa yang

\footnotetext{
${ }^{11}$ Eric Lichtblau. U.S. Hate Crimes Surge 6\%, Fueled by Attacks Moeslims. New York Times. 2016. http://www.nytimes.com/2016/11/15/us/politics/fbi-hate-crimesmuslims.html? $r=0$ diakses pada 17 November 2016
} 
membedakan antara trauma dan nostalgia adalah tentang reaksi yang dihasilkan oleh pengalaman. Jika trauma seringkali memunculkan reaksi keras terhadap sebuah kejadian yang memicunya, nostalgia muncul dengan reaksi yang jauh lebih terkendali dan seringkali hanya berupa penerimaan dan kedewasaan diri untuk menerima fakta dan pengalaman yang menciptakannya. Dunia dan tatanan kita nampaknya masih belum dapat menerima sejarah secara dewasa dan hal ini tentu sangat tidak menguntungkan bagi nostalgia, dimana ia muncul sebagai sebuah penerimaan yang utuh dan kedewasaan untuk membedakan sejarah dan masa kini. Sejumlah kegiatan untuk mengenang kejadian-kejadian bersejarah dan berdarah seringkali muncul ditengah-tengah kita. Pendirian monumen mengenang Perang Dunia II di Jerman, pemberian ucapan hari kemerdekaan dan ucapan hari raya oleh perwakilan negara kepada negara tempat ia ditugaskan, menjadi sejumlah bukti pendukung tentang nostalgia atas kejadian atau hari penting dari satu negara oleh negara lain. Jika kita mengecilkan hingga aspek masyarakat, sejumlah kegiatan amal dan kegiatan sosial sudah terjalin tanpa memandang latar belakang setiap peserta. Keterbukaan lembaga pendidikan swasta atau yayasan, sebagai contoh universitas-universitas Katholik yang sudah terbuka bagi mahasiswa non-Katholik menunjukan bahwa masyarakat telah belajar dari pengalaman dan ketika muncul isu yang kemungkinan memecahkan apa yang telah dicapai yang muncul adalah nostalgia dan kedewasaan untuk menghadapi isu-isu tersebut sekali lagi.

Pembentukan trauma dan nostalgia dalam alam pikiran manusia tidak dapat terlepas dari peran ingatan(memory). ${ }^{12}$ Apa yang menciptakan nostalgia adalah jelas sebuah peristiwa yang memiliki dampak besar, namun ingatan pasca peristiwa tersebut juga akan membentuk konstruksi alam pikiran, tidak hanya individu tetapi juga masyarakat atau bahkan dunia. Ingatan yang diperlukan untuk menciptakan kedewasaan dan sebuah nostalgia adalah ingatan yang bahagia. Ingatan yang bahagia bekerja layaknya keinginan, dan keinginan pun dapat terwujud atau tidak terwujud. ${ }^{13}$

\footnotetext{
12 Paul Ricoeur. Memory, History, and Forgetting. Chicago University. 2004. HIm 15 ${ }^{13} \mathrm{lbid}, 495$
} 
Ingatan yang memiliki keinginan yang terwujud mendekatkan diri manusia terhadap kedewasaan dan kesiapan mental untuk mendekati kebenaaran yang sesungguhnya. Sebaliknya, ingatan yang buruk dan menyakitkan secara terus menerus akan menjauhkan diri dari kebenaran dan kedewasaan diri. Kepuasan pada hal ini menjadi sesuatu yang dapat menjadi perubah keadaan. ${ }^{14}$ Kepuasan yang selalu tercapai akan membawa diri kepada keserakahan, tetapi kepuasan yang tidak pernah tercapai akan membawa diri pada keputusasaan yang menyempitkan pola pikir manusia itu sendiri. Siklus hidup umat manusia modern yang seringkali hanya mementingkan kepusasan individu dengan cara apapun, menyeret dunia lebih condong ke arah trauma dibandingkan dengan nostalgia.

Kembali dengan Ricoeur, yang berpendapat bahwa cara untuk lepas dari siklus ini adalah untuk belajar memaafkan. ${ }^{15}$ Sebuah kata yang terdengar klise namun dapat berdampak besar pada kehidupan umat manusia. Layaknya ingatan yang bermakna, maaf pun adalah abstraksi atas sebuah emosi, pemberian kesan yang membutuhkan subjektifitas dan kesiapan secara mental. Permasalahan yang seringkali dihadapi adalah ketidaksiapan mental dan ingatan imajinatif yang begitu kuat berakar di alam sadar manusia. Jumlah orang yang mengakui kesalahan akan selalu lebih kecil dibandingkan orang yang memiliki kebencian dan dendam pada orang yang meminta maaf. Dunia dengan berbagai masalah seperti kemiskinan dan berbagai permasalahan pelik lainnya akan terus terperangkap dalam siklus ini. Kedewasaan nampaknya masih menjadi sebuah impian yang belum dapat dicapai dalam waktu dekat.

\section{KESIMPULAN}

Melihat kompleksitas dari kejadian-kejadian yang pernah mengisi perjalanan waktu manusia, jawaban atas pertanyaan penulis adalah bahwa dunia masih dalam

\footnotetext{
${ }^{14} \mathrm{Ibid}, 497$

${ }^{15}$ lbid, 487
} 
kondisi trauma. Hegemoni ide yang muncul dalam masyarakat yang berperan menyusun konstruksi sosial dunia sangat berpihak kepada trauma. Sejumlah kejadian memang memungkinkan perkembangan manusia ke tingkat yang lebih dewasa tetapi kadarnya jauh lebih rendah dibandingkan kejadian yang menyeret manusia ke arah kebencian. Waktu sekalipun tidak dapat menyembuhkan kebencian, satu-satunya yang dapat merubah pola pikir manusia adalah manusia itu sendiri, bukan waktu atau bahkan semesta.

\section{DAFTAR PUSTAKA}

O'Shaughnessy, Brian. Consciousness and the World. Oxford University. 2002. Ricoeur, Paul. Memory, History, and Forgetting. Chicago University. 2004 Ricoeur,Paul. Time and Narrative. University of Chicago. 1990 New York Times. U.S. Hate Crimes Surge 6\%, Fueled by Attacks on Muslims. 2016 The Guardian. China Protests at Japanese PM's Latest WW2 Shrine Tribute. 2014 